\title{
Otizmli Bireylerin Görevi Tamamlama Davranışlarının Artırılmasında Sürekli ve Aralıklı Pekiştirme Kullanmanın Etkililiği
}

\author{
Abdurrahman MENGİ \\ Van Yüzüncü Y1l Üniversitesi \\ abdurrahmanmengi@yyu.edu.tr \\ ORCID: 0000- 0001-5903-254X \\ Yusuf ALPDOĞAN \\ Van Yüzüncü Y1l Üniversitesi \\ yusufalpdogan@yyu.edu.tr \\ ORCID: 0000-0002-6615-397X
}

Araştırma Makalesi

Geliş Tarihi: 02.04.2021

Revize Tarihi: 26.07 .2021

DOI: $10.31592 /$ aeusbed.908712

\section{Atıf Bilgisi}

Mengi, A. ve Alpdoğan, Y. (2021). Otizmli bireylerin görevi tamamlama davranışlarının artırılmasında sürekli ve aralıklı pekiştirme kullanmanın etkililiği. Ahi Evran Üniversitesi Sosyal Bilimler Enstitüsü Dergisi, 7(2), 659677.

\section{ÖZ}

Otizm spektrum bozukluğu (OSB), genelikle erken çocukluk döneminde etkilediği bireylerde belirginleşen, bireylerde sınırlı ilgi ve streotip/takıntılı davranışlara yol açan, bireylerin sosyal etkileşim ve iletişim becerilerini sınırlandıran, onların sosyalleşmesini olumsuz etkileyerek onları dış dünyaya karşı yabancılaştıran nöro biyolojik bir bozukluk olarak tanımlanmaktadır. Otizm, bireylerin birçok yönde problem davranış sergilemesine neden olmaktadır. Otizmli bireylerde problem davranışlarının azaltılması ancak özel eğitim yoluyla mümkündür. Otizmli bireylerin bir görevi yerine getirmeye çalışırken görevi yarıda bırakma, streotip davranışlar sergileme, sosyal etkileşim ve iletişimde sınırlılığa sahip olma gibi problem davranışların sağıltımı ancak özel eğitim yoluyla belli yöntem veya teknikler kullanılarak yapılmaktadır. Bu araştırma, otizmli bir bireyin görevi tamamlama davranışlarının artırılmasında sürekli ve aralıklı pekiştirmeyi birlikte kullanmanın etkisini ortaya koymak amacı ile yapılmıştır. Araştırma, tek denekli araştırma modellerinden ABAB modeli ile yürütülmüştür. Araştırmanın örneklemi beş yaşında otizmli bir erkek çocuktur. Araştırmada öğrencinin tercih ettiği pekiştireçleri belirlemek için dolaylı ve doğrudan pekiştireç belirleme yöntemleri kullanılmıştır. Araştırmada, otizmli bireyin gelişimine ve tercihlerine uygun olacak şekilde düzenlemeler yapıldığında, gerekli pekiştirmeler kullanıldığında bireyin görevi tamamlama davranışlarının arttığ bulgulanmıştır. $\mathrm{Bu}$ araştırmada sürekli ve aralıklı pekiştirmenin, örneklemin görevi tamamlama davranışlarında artmasına ve görevi sürdürmede olumlu etkiye yol açtığına ilişkin bir sonucuna ulaşılmıştır. Araştırmada, ileri araştrımalar için bu konunun birden çok örnekleme yönelik yapılması ve uygulamada başka bir öğretim modeli kullanılarak araştırmanın yürütülmesi önerilmektedir.

Anahtar Kelimeler: Otizm spektrum bozukluğu, görevi tamamlama davranışları, sürekli ve aralıklı pekiştirme, problem davranışlar.

\section{The Effectiveness of Using Continuous and İnterval Reinforcement in İncreaing Task- Achieving Behaviors of Individuals with Autism}

\begin{abstract}
Autism spectrum disorder (ASD) is defined as a neurobiological disorder that usually becomes apparent in individuals affected in early childhood, leads to limited attention and stereotype / obsessive behaviors in individuals, limits individuals' social interaction and communication skills, negatively affects their socialization and alienates them from the outside world. Autism causes individuals to exhibit problem behaviors in many ways. The reduction of problem behaviors in individuals with autism is only possible through special education. The treatment of problem behaviors such as abandoning the task, exhibiting stereotypical behaviors, having limitations in social interaction and communication of individuals with autism while trying to fulfill a task is only done by using certain methods or techniques through special education. This study was conducted to reveal the effect of using continuous and intermittent reinforcement together on increasing task completion behavior of an individual with autism. The research was conducted with ABAB model, which is one of the single subject research models. The sample of the study is a five-year-old boy with autism. In the study, indirect and direct reinforcement determination methods were used to determine the reinforcers preferred by the student. In the study, it was found that when arrangements are made in accordance with the development and preferences of the individual with autism, when the necessary reinforcements are used, the individual's task completion behaviors increase. In this study, it was concluded that continuous and intermittent reinforcement leads to an increase in the sample's task completion behavior and has a positive effect on maintaining the task. In the study, it is suggested that this subject should be done
\end{abstract}


for more than one sample for further research and the research should be carried out using another teaching model in practice.

Keywords: Autism spectrum disorder, task completion behaviors, continuous and intermittent reinforcement, problem behaviors.

\section{Giriş}

İnsan, içinde yaşadığı toplumla etkileşimde bulanan ve iletişim kuran sosyal bir varlıktır. Geçmişten günümüze kadar insanlar arasındaki etkileşim ve iletişim biçiminde önemli oranda değişimler ve gelişmeler olmuştur (Richman, Wacker ve Winborn, 2001). İnsanlar arası etkileşim ve iletişimde görülen bu gelişmelere rağmen insanlarla sosyal etkileşime ve iletişime geçme konusunda bazı bireyler sorunlar yaşayabilmektedirler. Günümüzde, otizm spektrum bozukluğu (OSB) olan bireyler, bu tür sorunları yoğun bir şekilde yaşayan bireylerin başında gelmektedirler (Aydın, 2008). OSB, Yunancada kendisi anlamına gelen "autos" ve Latince'de bir görüşün ya da sürece ilişkin tak1 eki olarak kullanılan "ismus" sözcüklerinin birlikte kullanılmasıyla oluşmuştur (Kuhn ve Cahn, 2004, ss. 361-366). İlk olarak tıbbi bağlamda tanımlamaya çalışan psikiyatrist Leo Kanner OSB terimini; bireyleri yaşam boyu etkileyen bazı tekrarlayıcı davranışlara, bireylerde görülen konuşma gecikmesi veya iletişim becerilerindeki sınırlılığa, sosyal etkileşimdeki yetersizliğe dikkat çekerek tanımlamıştır (Kanner, 1943, ss. 217-250). OSB bireylerde stereotipik davranışların sergilenmesine, aynı davranışları sürdürmekten hoşlanmasına, nesnelere normalden fazla bağlanmasına ve sosyal olarak etkileşimden kaçınmasına yol açmaktadır (Darıca, Abidoğlu ve Gümüşçü, 2002). Dolayısıyla OSB, bireylerin sosyalleşmesini olumsuz etkileyen ve onları kendi doğasına ve topluma karşı yabancılaştıran bir işleve sahiptir. Başka bir ifadeyle OSB'yi, "bireylerin sosyalleşmesini olumsuz etkileyen ve onları dış dünyaya karşı yabancılaştıran" (Wall, 2004, s. 5) nöro biyolojik bir bozukluk olarak da tanımlamak mümkündür (Kunt, 2010). OSB'li bireylerin diğer bireyler ile iletişime geçme konusunda sorunlar yaşaması, onlar ile diğerleri arasındaki sosyal etkileşim ve iletişime yeni bir boyut kazanmaktadır. Böylece OSB, OSB'den etkilenen bireyler ile diğer bireyler arasında farklı bir ilişki biçiminin ortaya çıkmasına yol açmaktadır. "Bu iliş̧i biçiminde, sosyal etkileşim giderek etkileşimsizlik veya negatif etkileşim halini almaktadır. Birincil ve ikincil sosyal ilişsilerin yerine, etkileşim ve iletişimin çoğu zaman tek taraflı olduğu, ilişkinin asgari ihtiyaçlar üzerinden ve zorunlu bir şekilde yürütüldüğ̈̈ bir ilişkiler biçimi yer almaktadır" (Çopuroğlu ve Mengi, 2014, s. 611).

Amerikan Psikiyatri Birliğinin hazırladığı Ruhsal Bozuklukların Tanısal ve İstatistiksel El Kitab1 (Diagnostic and Statistical Manual of Menatal Disorder [DSM-5]) OSB'yi, erken çocukluk dönemlerinde ortaya çıkan, sosyal etkileşim ve sosyal iletişim alanlarındaki yetersizlikler ile sınırlı ilgi/tekrarlayıcı davranışlarla kendini gösteren gelişimsel bir bozukluk olarak açılamıştır (DSM-5, 2013). OSB olan bireylerin dil ve iletişim becerilerinde, sosyal etkileşim becerilerinde, zihinsel işlevlerinde ve motor becerilerinde aksamalar görülmektedir (Clifford, Young ve Williamson, 2007). Dolayısıyla OSB'li bireyler tipik gelişen akranlarından farklı bir gelişim seyretmektedirler (Mengi, 2014). OSB olan bireyler her ne kadar akranlarından farklı davranış ve gelişim özellikleri gösterseler de, bu bireylerin birbirine benzeyen davranışları bulunmaktadır (Özdemir, 2014). Bunlar: duygularını karşı tarafa aktarmada yetersizlik yaşama, çoğunlukla göz teması kurmaktan kaçınma, sözel ve sözel olmayan ifadelere tepkisiz kalma ve sosyal etkileşim ile iletişimde sınırlılık yaşama gibi problemlerdir. Ayrıca zihinsel bozukluk, stereotipik davranışların varlı̆̆ı, problem davranışlar sergileme, duyusal organlarda aşırı hassaslık, düzenlerinin değişmesine karşı aşırı tepki verme, saldırgan davranışlarda bulunma, beslenme ve uyuma bozuklukları, uygun jest ve mimikleri kullanmada yetersizlik gibi sorunlar da yaşamaktadırlar (Töret, 2016).

OSB olan bireylerde sözel olmayan iletişim becerilerinde, alıcı dil becerilerinde ve ifade edici dil becerilerinde önemli sorunlar görülmektedir (Diken ve Bakkaloğlu, 2016; Webber ve Scheuermann, 2008). Dili becerilerindeki sınırlılık onların problem davranış yoluyla kendilerini ifade etmelerine dönüşmektedir (Winborn, Wacker, Richman, Asmus ve Geier, 2002). Oysa tipik gelişim gösteren bireyler dil becerileri yoluyla diğerleriyle iletişime geçebildikleri için bebeklikte bile kendilerini ifade etmeye ilişkin problem davranışları ortadan kalkmaktadır (Carr, Levin, McConnachie, Carlson, Kemp and Smith, 1994). Ancak OSB olan bireylerde sosyal etkileşim ve iletişimdeki sınırlılık önemli bir problem davranışa dönüşmektedir (Erbaş, 2001; Kadak, Demir ve 
Doğangün, 2013). Hatta günlük yaşamlarında ciddi sorunlara yol açmaktadır (Durand, 1999). Keza OSB olan bireylerin sosyal etkileşimde yaşadıkları iletişim sorunları, onların problem davranışlar sergilemesine neden olmaktadır (Girli, 2004).

Diken ve Bakkaloğlu (2016) OSB olan bireylerin sergiledikleri problem davranışları, etkileşimlerini ve öğrenmelerini olumsuz etkileyen, görevlerini tamamlamalarını engelleyen fiziksel veya sözel öfke şeklinde ortaya çıkan davranışlar olarak açıklamışlardır. OSB olan bireyler normal hayat içerisinde üstlenmeleri gereken rolleri ya da gerçekleştirmeleri gereken görevlerini yapmakta problem yaşamaktadırlar. Bu bireyler gerçekleştirmeleri gereken görevlere ya hiç başlamamaktadırlar ya da başladıkları görevleri yarıda bırakmaktadırlar. OSB olan bireylerin günlük hayatta yaşadıkları bu problem davranışlar onların hayat akışlarını olumsuz etkilemektedir. Problem davranışlar, OSB olan bireylerin kendilerine verilen herhangi bir göreve katılmaları, görevi sürdürmeleri ile tamamlamaları üzerinde olumsuz etkiler bırakmakta ve bu bireylere yönelik gerçekleştirilen eğitsel müdahaleleri de olumsuz etkilemektedir (Sucuoğlu, 2012). Bireylerin yaşamı üzerinde olumsuz etkisi olan problem davranışların (Alan ve Özsoy, 2019) azaltılması OSB olan bireylerin sosyalleşmelerinde büyük önem taşımaktadır (Durand ve Carr, 1992). Ayrıca problem davranışların ortadan kaldırılması bu bireylerin eğitim hayatlarına katılımlarını olumlu etkilemekte, eğitim-öğretim faaliyetlerine katılım sıklığını ve sürelerini de olumlu yönde etkilemektedir (Erbaş, 2017). OSB olan bireylerin görevi yarıda bırakma, vurma, 1sırma, dağıtma gibi problem davranışlarının azaltılması ve ortadan kaldırılması için, bu bireylerin temel becerilerinin eğitim yoluyla arttırılması gerektiği vurgulanmaktadır (Sönmez ve Vuran, 2008; Sucuoğlu, 2009). Bu nedenle alanyazında OSB olan bireyler ve aileleri için özel eğitim hizmetleri önerilmektedir (Kurt ve Subaşı Yurtçu, 2017). OSB olan bireyler, pek çok beceriyi öğrenmek için yapılandırılmış bir eğitim-öğretim ortamına ihtiyaç duymaktadırlar (Tekin İftar ve Değirmenci, 2012). Dolayısıyla OSB olan bireylerin yetersizlikten etkilenme oranına göre özel eğitim hizmetleri almaları gerekmektedir.

OSB olan bireylerin problem davranışlarının azaltılmasında kullanılacak yöntemlerin kanıta dayalı olması önemlidir (Odom, Coolet Klinenberg, Rogers ve Hatton, 2010). Bir yöntemin kanıta dayalı olabilmesi için çok sayıda uygulamanın benzer sonuçlar vermesi gerekir (Kurt, 2012; Yücesoy Özkan, 2014). Amerikan Birleşik Devletlerinde OSB olan bireyler için uygulamaları inceleyen Ulusal Mesleki Gelişim Merkezi (The National Professional Development Center On Autism Spectrum Disorders [NPDC]) kanıta dayalı bilimsel dayanağı olan uygulamaları belli dönemlerde ortaya koymaktadır (Wong vd., 2013; Akt. Cavkaytar, 2015). Amerikan Ulusal Mesleki Gelişim Merkezi'nin yayınladığ The National Clearinghouse on Autism Evidence and Practice (NCAEP) 2020 raporunda, OSB olan bireyler için 28 uygulama kanıta dayalı ve bilimsel dayanaklı uygulama olarak görülmüştür. Bunlardan birkaçı şöyledir: Ayrık denemelerle öğretim, beceri öğretimi, pekiştirme, öncüle dayalı uygulamalar, sönme, video model, doğal öğretim, doğrudan öğretim, sosyal beceri öğretimi, davranışsal ivme, ipucu sunma, kendini yönetme olarak sıralanabilir (NCAEP, 2020).

OSB olan bireylerin eğitimlerinde etkisi deneysel araştırmalarla ortaya konulmuş kanıta dayalı veya bilimsel dayanaklı uygulamalar arasında pekiştirme de yerini almıştır. Pekiştirmeler, özel eğitime gereksinimi olan bütün bireylerde olduğu gibi OSB olan bireylerde de yoğun bir şekilde kullanılan uygulamalardan biridir. Pekiştirme, hedef davranışı izleyen ve ilerde aynı davranışın gerçekleşme ihtimalini artırmak üzere ortama bir uyaranın dâhil edilmesi ya da ortamda mevcut olan bir uyaranın o ortamdan kaldırılması şeklinde tanımlanmaktadır (Tekin İftar ve Kırcaali İftar, 2019, s. 35). Pekiştirme bir davranışın ardından ortama hoşa giden bir uyaran eklenmesi ya da itici olan uyaranın kaldırılması durumunda, davranışın ilerde gerçekleşme olasılığını ve sıklığını arttırma süreci olarak da tanımlanmaktadır (Besler ve Süzer, 2019, s. 216). Pekiştirmeler, olumlu pekiştirme, olumsuz pekiştirme ve otomatik pekiştirme olmak üzere üç türde incelenebilir (Yücesoy Özkan, Kaya ve Gülboy, 2017 s. 274). Olumlu pekiştirme, bir davranışın ardından ortama bir uyaranın eklenmesiyle o davranışın ilerde yapılma olasılığının artırılması iken; olumsuz pekiştirme bir davranışı izleyen durumda ortamdan bir itici uyaranın çekilmesiyle o davranışın ilerde yapılma olasılığının artırılmasıdır (Tekin İftar ve Kırcaali İftar, 2019, s. 40). Her iki pekiştirme türünde de davranışın ilerde artması söz konusudur. Otomatik pekiştirme ise herhangi bir aracı olmaksızın davranışın kendiliğinden pekiştirme etkisi göstermesi durumudur (Yücesoy Özkan, Kaya ve Gülboy, 2017, s. 279). 
OSB olan bireylerin davranışlarının sıklık ya da sürelerinin artırılmasında pekiştireçlerin kullanılması önemlidir (Peterson, Lerman ve Nissen, 2016). Pekiştireç, bireyin davranışının hemen ardından bireye sunulan hoşa giden uyaran olarak tanımlanır (Özyürek, 2000). Alanyazında pekiştireçler temelde birincil ve ikincil pekiştireçler olarak ikiye ayrılmaktadır. Birincil pekiştireçler, koşulsuz veya öğrenilmemiş pekiştireçler (yiyecek-içecek pekiştireçler) olarak tanımlanırken; ikincil pekiştireçler, koşullu veya öğrenilmiş pekiştireçler (övgü-sembol pekiştireçler) olarak tanımlanmaktadır (Besler ve Süzer, 2019, s. 226). Bireysel özellikler nedeniyle pekiştireçler kişiden kişiye göre değişir ve bir kişi için anlam ifade eden bir uyaran bir başkası için aynı işlevi görmeyebilir. Benzer bir şekilde aynı bireyde etkili olan bir pekiştireç zaman içinde değişkenlik gösterip etkisini yitirebilir (DeLeon vd., 2001). Dolayısıyla bir davranış değiştirme programı hazırlanacağı zaman bireye uygun etkili pekiştireçlerin ve pekiştirme tarifelerinin belirlenmesi önemlidir (Rush, Mortenson ve Birch, 2010; Toper Korkmaz, 2017). Başka bir deyişle pekiştireçlerin işlevsel olarak amaca hizmet edebilmesi için pekiştirmenin belli kurallar dâhilinde yapılması gerekmektedir. Pekiştireçlerin hangi sıklık ya da sürede sunulacağını pekiştirme tarifeleri belirler. Bu tarifeler ise bireyin performans durumuna göre gerçekleştirilen düzenlemeler sonucunda sürekli pekiştirmeden hiç pekiştirmemeye doğru değişebilmektedir (Tekin İftar ve Kırcaali İftar, 2019). Pekiş̧irme tarifeleri sürekli pekiş̧irme, aralıklı pekiştirme olarak ele alınır (Lee ve Belfiore, 1997). Sürekli pekiştirme, hedef davranışın her sergilenişinde pekiştireçlerin sunulması iken aralıklı pekiştirme, her uygun davranıştan sonra değil, belli uygun davranışlardan sonra pekiştireçlerin sunulmasıdır (Lee ve Belfiore, 1997; Tekin İftar ve Kırcaali İftar, 2019, s. 41; Yücesoy Özkan, Kaya ve Gülboy, 2017, s. 302). Sürekli pekiştirme ile beceri veya kavram öğretildiği zaman her doğru tepkinin pekiştirilmesi yapılarak bireyin davranışları hızlı ve etkili bir şekilde ayırdedici uyaran kontrolüne sokulmaya çalışılır. Böylece bireyde yeni öğrenmelerin daha çabuk gerçekleşmesi sağlanmış olur (Özyürek, 2010, s. 107). Ancak pekiştirmeye son verildiğinde sönmenin hızlı gerçekleşme ve öğrenmelerin çok çabuk unutulma riski doğmaktadır. Dolayısıyla sürekli pekiştirme ile meydana gelen bu riskli durumun önlenmesi için aralıklı pekiştirme ile davranış, beceri ve öğrenmelerin kalıcılığı sağlanmaya çalışılır. Aralıklı pekiştirme tarifesi ile pekiştirmeden önce belli bir sayıda davranışın oluşmasına ve belli bir sürenin geçmesine dikkat edilir. Aralıklı pekiştirme tarifesi, bireyin davranışı pekiştirilmeden önce tepki sayısı (oranlı tarife), geçen süre (aralı tarife), pekiştireçlerin tahmin edilebilir olması (sabit) ve pekiştireçlerin tahmin edilemez olması (değişken olması) şeklinde dört farklı tarife dikkate alınır (Özyürek, 2010, s. 108).

OSB olan bireylerin bağımsız işlevsellik becerilerini geliştiren ve başkalarına bağımlılığı azaltan, diğer bir ifadeyle görevi bağımsız bir şekilde tamamlamayı amaçlayan müdahalelere ihtiyaç duyulmaktadırlar (Hume, Loftin, ve Lantz, 2009). Görevi tamamlama davranışlarıyla ilgili olarak son yıllarda yapılan araştırmalar, teknolojik aygıtlar yoluyla beceri analizi yapılan görevlerin bağımsız bir şekilde tamamlanmasının olumlu sonuçları olduğunu ortaya koymaktadır. Bouck, Savage, Meyer, Taber Doughty ve Hunley (2014), OSB olan üç birey ile bağımsız görevi tamamlama davranışlarını çalışmışlardır. Araştırmacılar, örneklemlerin düşük teknolojili müdahale (kağıt/kalem) ve yüksek teknolojili müdahale (iPad) kullanarak kendi kendini gözlemlerken yemek hazırlama görevlerini tamamladıklarında görev bağımsızlığı düzeylerinde bir fark olup olmadığını belirlemeye çalışmışlar. Her iki müdahalenin de yönlendirme ihtiyacını azaltarak bağımsız bir şekilde görevi tamamlamada etkili olduğunu ancak bireylerin iPad kullanırken daha az ipucu ve pekiştireçlere ihtiyaç duydukları görülmüştür. Rosenbloom, Wills, Mason, Huffman ve Mason, (2019) araştırmalarında teknolojik olarak sağlanan kendi kendini izleme müdahalesinin (I-Connect) görevi bağımsız bir şekilde tamamlama davranışları üzerinde ki etkisine de bakmışlar. Araştırmayı dört OSB olan birey ile yürütmüşler. Araştırma sonuçları, öğretimin görevi bağımsız bir şekilde tamamlama davranışları üzerinde olumlu etkileri olduğunu göstermiştir. Türkçe alanyazın incelendiğinde OSB'li bireylerin görevi tamamlama davranışlarının artırılmasında pekiştirmelerin kullanıldığ 1 herhangi bir araştırmaya rastlanılmamıştır. Bununla beraber alanda pekiştirmelerin kullanıldığ 1 çalışma sayısının da sınırlı (Dayı ve Şafak, 2018; Eldeniz Çetin 2017; Erbaş, 2005; Özkubat ve Töret, 2014; Sönmez ve Varol, 2008; Sönmez ve Varol, 2009) olduğu görülmüștür. Bazı araştırmalar öğretmenlerin sınıf ortamlarında eğitimi engelleyen durumlar arasında öğrencilerin kendilerine verilen görevlere katılmamalarının önemli bir yer aldığını ifade etmektedirler (Acar, 2000; Brown ve Bullock, 1972). OSB olan bireylerin etkinliklere karşı ilgisiz olmalarının (DSM-5; Diken ve 
Bakkaloğlu, 2016) kendilerine verilen görevleri tamamlama davranışları üzerinde olumsuz bir etki bıraktığı düşünülmektedir. Diken ve Bakkaloğlu (2016) OSB olan bireylerin eğitimlerinde yapılan düzenlemelerin bireyin gelişimine ve tercihlerine uygun olarak gerçekleştirilmesinin eğitim çıktıları üzerinde olumlu etkisi olduğunu düşünmektedirler. Ayrıca, OSB olan bireylere yönelik eğitim-öğretim programı hazırlanırken, bireyin hâlihazırdaki performans düzeyinin belirlenmesinden, etkinliklerde kullanılacak pekiştireçlere kadar belli durum ve süreçlerin dikkate alınması önemlidir.

$\mathrm{Bu}$ araştırmada görevi tamamlama davranışları, OSB olan bireyin kendisine verilen göreve ilgi göstermesi/katılması, görevi sürdürmesi ve tamamlaması olarak ele alınmıştır. Araştırma, OSB olan bireylerin bireysel özelliklerine ve tercihlerine uygun öğretimsel düzenlemeler yapılıp, uygun pekiştirmeler kullanıldığında, onların görevi ne düzeyde tamamladıkları, görevi tamamlama davranışlarının artırılmasında sürekli ve aralıklı pekiştirme kullanmanın etkililiğinin ne düzeyde olduğunu sorgulamaktadır. Dolayısıyla araştırmada, görevi tamamlama davranışlarının artırılmasında sürekli ve aralıklı pekiştirme kullanımının ne derece etkili olacağ hususun araştırılması alanyazına katkı sağlaması bakımından önemlidir. Bu nedenle, araştırmanın amacı, otizmli bir bireyin görevi tamamlama davranışının artırılmasında sürekli ve aralıklı pekiştirme kullanmının etki düzeyini ortaya koymaktır. $\mathrm{Bu}$ amaçla, araştırmada; "Otizmli bireylerin görevi tamamlama davranışlarının artırlmasında sürekli ve aralıklı pekiştirmeyi birlikte kullanılmanın etkililiği ne düzeydedir?" sorusuna yanıt aranmıştır.

\section{Yöntem}

Araştırmanın bu kısmında araştırma modeline, araştırmanın örneklemine, bağımlı ve bağımsız değişkenlere, ortam ve araç-gereçlere, pekiştireçler ve pekiştirmeye karar verme sürecine, verilerin toplanmasına, araştırma verilerin güvenirliğine, sosyal geçerliğine, verilerin analizine, araştırma etiğine yer verilmiştir.

\section{Araştırma Modeli}

$\mathrm{Bu}$ araştırma, tek denekli araştırma modellerinden $\mathrm{ABAB}$ modeli ile yürütülmüsştür. $\mathrm{AB} A \mathrm{~B}$ modeli özellikle ABA modelinin sınırlılıklarını ortadan kaldırmak üzere geliştirilmiştir. Geriye çekmeli modellerden olan $\mathrm{ABAB}$ modeli, bağımlı değişken ile bağımsız değişken arasındaki işlevsel ilişkiyi (tahminde bulunma, doğrulama ve yineleme) kuran güçlü bir model olmasından dolayı tek denekli araştırmalar arasında sıklıkla kullanılan bir modeldir (Tekin İftar, 2012). Bir uygulamanın etkililiği $\mathrm{ABAB}$ modeliyle incelenmek istendiğinde öncelikle birinci başlama düzeyi A1 düzenlenir. Birinci başlama düzeyi evresinde hiçbir uygulama yapılmaz, belirlenen gözlem aralıklarında hedef davranışlar kaydedilir. Kararlı veri elde edildiğinde B1 evresine geçilir ve uygulama yapılır. Birinci uygulama evresinde kararlı veri elde edildiğinde bağımlı değişkenin bağımsız değişkene bağlı olarak değiştiği düşünülür ve tahminde bulunulur. Tahmini doğrulamak için birinci başlama düzeyindekine benzer olarak herhangi bir uygulama yapılmadan A2 oturumları düzenlenir, davranışlar kaydedilir. İkinci başlama düzeyindeki veriler birinci uygulama evresindeki verilere benzemiyorsa ve birinci başlama düzeyindeki veri eğilimlerine benziyorsa tahmin doğrulanır (Tekin İftar, 2012). Yapılan doğrulamanın yinelenmesi için ikinci bir uygulama olan B2 oturumları düzenlenir. Bu şekilde güçlü bir işlevsel ilişki kurulur.

\section{Çalışma Grubu}

Araştırmanın örneklemi belirlenirken önkoşul olarak OSB tanısı almış 4-7 yaş aralığında olan, kendisine verilen herhangi bir göreve/etkinliğe başlayamama ya da etkinliği yarıda bırakma problem davranışları olan ve anne-babasının çalışmaya istekli olma şartı aranmıştır. Bunun için önkoşul becerileri taşıyan üç örneklem belirlenmiştir. Değerlendirme aşamasında örneklemlerden birinin annesinin trafik kazası geçirmesi nedeniyle ailesi tarafından araştırmadan çekilmiştir. Başka bir örneklem ise kendisinde var olan kemik rahatsızlığının artması nedeniyle yine ailesi tarafından araştırmadan çekilmiştir. Bunun için araştırmacılar, önkoşul şartları taşıyan tek bir örneklem ile araştırmaya devam edilmesine karar vermişlerdir. Araştırmanın örneklemi, OSB tanısı olan 5 yaşında 
bir erkek çocuğudur. Araştırmada gizlilik ve etik ilkelere bağlı kalınmak şartıyla örneklemin gerçek ismine yer verilmemiş olup örneklem Mehmet kod adıyla kodlanmıştır. Örneklemin, giyinmesoyunma, yemek yeme gibi özbakım becerileri ve diğer birçok günlük yaşam becerileri annesi tarafindan gerçekleştirilmektedir. Mehmet, tuvalet becerilerini henüz kazanmamıştır. Mehmet'in günlük olarak tükettiği yiyecekler sınırlıdır. Mehmet genellikle süt, çorba, fıstık, çubuk kraker tüketmektedir. Mehmet, akranlarıyla iletişim kurmaktan kaçınmakta, verilen görevlere ya hiç başlamamakta ya da yarıda bırakmaktadır. Mehmet, kendisine bir yönerge verildiğinde çoğu zaman yönergeyi yerine getirmemektedir. Mehmet bir şey isteyeceği zaman ya da kendisine verilen bir şeyi ret edeceği zaman genellikle yüksek sesle ağlamakta ve krize girmektedir. Mehmet anasınıfina gitmektedir. Gittiği anasınıfında da aynı problem davranışları sergileyip isteklerine kavuşmaktadır. Sınıf ortamında genellikle bir köşede oturup etkinliklere katılmamaktadır. Öğretmen, kendisine bir görev verdiği zaman Mehmet öğretmeni duymuyormuş şeklinde davranmaktadır. Öğretmen, Mehmet'in görevi yapması konusunda 1srarlı davrandığ 1 zaman ise Mehmet çığlık atarak ağlamaya başlamaktadır.

\section{Bağımlı ve Bağımsız Değişkenler}

$\mathrm{Bu}$ araştırmanın bağımlı değişkeni örneklemin görevi tamamlama davranışlarıdır. Araştırmanın bağımsız değişkeni sürekli ve aralıklı pekiştirmenin kullanılmasıdır. Pekiştireçler, bireysel özellikler nedeniyle kişiden kişiye göre değişen (DeLeon vd., 2001), bireyin performans durumuna göre gerçekleştirilen düzenlemeler sonucunda sürekli pekiştirmeden hiç pekiştirmemeye doğru düzenlemeler gerektiren (Tekin İftar ve Kırcaali İftar, 2019) ve bireyin davranışının hemen ardından bireye sunulan hoşa giden uyaran olarak açıklanmaktadır (Özyürek, 2000). Bu araştırmada pekiştireçler, OSB olan bir bireyin görevi tamamlama davranışlarını artırmak amacıyla uygulanmıştır.

\section{Veri Toplama Araçları}

Veri toplama araçları başlığı altında ortam ve araç-gereçler bilgisi, pekiştireçler ve pekiştirmeye karar verme süreci detaylı olarak açıklanmıştır.

\section{Ortam ve Araç-Gereçler}

Araştırmanın uygulaması, Van ilinde örneklemin yaşadığı evin bir odasında gerçekleştirilmiştir. Odanın eni altı uzunluğu sekiz metre olup odanın büyüklüğü 48 metre karedir. Uygulamanın gerçekleştirileceği ev ortamı, örneklemin dikkatini dağıtacak uyaranlardan arındırılmış ve etkinliklerde örneklemin odada rahatça oturabileceği ve araştırmacının da etkinlikleri sunabilmesi için odaya bir masa, iki sandalye yerleştirilmiştir. Örneklemin, masa dışında yerde oturmak istemesi durumundaki ihtiyaçları için yere bir halı ve iki minder konulmuştur. Araştırma ortamında araştırmacı ve öğrenci dışında kimsenin olmamasına özen gösterilmiştir. Uygulamada kullanmak için ortamda ses kartları, küçük topların içinde bulunduğu bir kutu, öğrencinin topları içine atması için üzerinde dört küçük penceresi olan boş bir kutu ve ahşaptan yapılmış olan üzerinde sekiz adet takıp-çıkarmalı hayvan figürlü tak-çıkar legosu bulundurulmuştur. Ayrıca uygulama ortamında pekiştireç olarak kullanmak için tablet bilgisayar, çubuk kraker, antep fıstığ 1 ve şeker bulundurulmuştur.

\section{Pekiştireçler ve Pekiştirmeye Karar Verme Süreci}

$\mathrm{Bu}$ araştırmada örneklemin tercih ettiği pekiştireçleri belirlemek için dolaylı ve doğrudan pekiştireç belirleme yöntemleri kullanılmıştır. Dolaylı yöntem için, örneklemin öğretmeninden, annebabasından görüşmeler yoluyla kendisinin tercih ettiği pekiştireçler hakkında bilgi edinilmiştir. Dolaylı gözlemlerde elde edilen bilgiler kayıt edilmiş ve doğrudan gözlemler için deneme temelli değerlendirme oturumları düzenlenmiştir. Oturumlar, çift uyaran sunumu yoluyla yapılmıştır. Bu sunum yoluyla toplanan verilerle, her bir pekiştirecin kaç defa seçilmiş olduğu hakkında bilgi elde edilmiş ve pekiştireçler daha sonra en çok tercih edilenden en az tercih edilene doğru sıralanmıştır. Yapılan değerlendirmeler sonucunda yiyecek pekiştireçleri çubuk kraker, antep fistığı, şeker; sosyal 
pekiştireçler aferin, harikasın ve etkinlik pekiştireci olarak ise her etkinlik tamamlandıktan sonra tablet bilgisayar yoluyla oyun oynama pekiştireçlerinin kullanılmasına karar verilmiştir.

Görüşme ve gözlemlerde örneklemin, kendisine görev verildiğinde genellikle görevlerini yapmaktan kaçındığı ve çoğu zaman ağlama davranışını gösterip görevleri tamamlamamakta direndiği görülmüştür. Örneklemin anne-babası ve öğretmeni böyle durumlarla başa çıkmak için örnekleme sevdiği yiyecekler ya da tablet bilgisayar vererek örneklemin kısa süreli olarak istenilen davranışı sergilemesini sağlamışlardır. Örneklemin sergilediği bu davranışlar incelendiğinde, uygulama sürecinde pekiştireçlerin etkili ve sistematik bir şekilde kullanılarak öğretim yapılabileceği, dolayısıyla görevi tamamlama becerisinin kazandırılabileceği düşünülmüştür. Bu nedenle bu araştırma sürecinde, örneklemin sergileyeceği her istendik davranış öncelikle sürekli pekiştirilerek sıklık ya da süresi arttırıldıktan sonra aralıklı pekiştirme kullanılmasına karar verilmiştir.

\section{Verilerin Toplanması ve Analizi}

Araştırma uygulamasının başlama düzeyi oturumları, uygulama süreci ve izleme oturumlarına ilişkin bütün verileri aynı ortamda toplanmıştır. Uygulamaları kaydetmek için odanın bir köşesine kamera yerleştirilmiştir. Her oturum video kaydı tekniğiyle kayıt edilmiştir. Her uygulama, oturum sonunda bilgisayara aktarılmış ve kameradan silinmiştir.

\section{Başlama Düzeyi Oturumları}

Başlama düzeyi oturumlarında örnekleme herhangi bir öğretim ve pekiştirme sunulmadan yönergeler şu şekilde: "söylediğim sesi tekrar et, topu kutuya at, legolar yerlerine uygun olarak yerleştir" verilmiştir. Örneklem, kendisine verilen görevleri yapmayarak, ağlama, odadan çıkmaya çalışma, meteryalleri firlatma davranışlarını sergilemiştir. Bu davranışlar örneklemin bir görev karşısında, görevden kurtulmak için kaçma işlevine hizmet eden davranışlar olarak belirlenmiştir. Başlama düzeyi oturumlarında örneklemin görevi yerine getirmemek için sergilediği görevi tamamlamama davranışlarının tanımı yapılmaya çalışılmışıı. Örneklem, öğretmenin verdiği görevleri yapmayıp, görevde bulunan materyalleri eliyle iterek sağa-sola firlatıp, yerinden kalkarak görevden kaçmak için ağlamıştır. Başlama düzeyi oturumları video kameraya kaydedilmiştir. Örneklemin görevi tamamlama davranışlarının kaydı için süre kaydı tekniği kullanılmıştır. Böylece örneklem, kendisinden bir görevi tamamlanması istenildiğinde, görevde bulunan etkinliklere katılma süresi tutulmuştur. Başlama düzeyi oturumlarında en az üç oturum üst üste kararlı veri elde edildikten sonra uygulama sürecine geçilmiştir.

\section{Uygulama Süreci}

$\mathrm{Bu}$ araştırmanın uygulama süreci, hafta içi her gün örneklemin dikkat süresinin en fazla olduğu sabah saat 9 ile 10 arasında yapılmıştır. Uygulamaya başlamadan önce araştırmacı, örneklemin herhangi bir ihtiyacı olup olmadığını sormuştur. Uygulama esnasında örnekleme uyması gereken kuralları şöyle: "beni iyice dinle, söyle dediğimde söyle, göster dediğimde göster, yap dediğimde yap, yerine otur dediğimde otur" hatırlatılmıştır. Daha sonra araştırmacı tafarından, örneklemin etkinlik kurallarına uyup kendisine verilen görevleri yapmaya başladığında ve etkinliklere katılarak görevi tamamladıktan sonra kazanacağı pekiştireç örnekleme şu şekilde "söylediğim sesi tekrar et dediğimde tekrar edersen, topu kutuya at dediğimde topu kutuya atarsan ve legolart uygun yerlere yerleştir dediğimde yerleştirirsen sana çubuk kraker ya da antep fistı̆̆ vereceğim. Sana verdiğim görevleri tamamladiktan sonra ise tablet bilgisayar ile oynamana izin vereceğim" hatırlatılmıştır.

Araştırmacı, örneklemi sürekli pekiştirme ve aralıklı pekiştirme sürecine ilişkin şu şekilde: "derste yap dediklerimi yaptığında, göster dediklerimi gösterdiğinde, söyle dediklerimi söylediğinde sana çubuk kraker vereceğim. Ama beni dinlemezsen, verdiğim görevleri yapmazsan, çubuk kraker, antep fistığ ve tablet bilgisayarla oynamayı kazanamayacaksın” bilgilendirmiştir. Bu bilgilendirmeler ilk başlarda sürekli pekiştirme için yapılmış, daha sonraki öğretim oturumlarında aralıklı pekiştirme için de yapılmıştır. 
Araştırmacı, örneklem ile a- söylediğim sesi tekrar et, b- topu kutuya at c- legoları yerlerine uygun olarak yerleştir şeklinde üç hedef beceri üzerinden uygulama süreci yürütmüştür. Birinci beceri için örnekleme, masada bulunan ses kartlarını sırayla kaldırıp seslendirerek "söylediğim sesi tekrar et" yönergesini vermiştir. Akabinde örneklem yönergeyi tekrar ettiğinde uygulamacı örnekleme yiyecek pekiştireci vermiş ve sosyal pekiştireç ile davranışını pekiştirmiştir. Yermi tane ses kartı bu şekilde uygulandıktan sonra ikinci hedef beceri olan topları kutuya atma becerisine geçilmiştir. Toplam yermi adet topu kutusundan alıp dört pencereli boş kutuya atması için araştırmacı, örnekleme "topları kutuya at" yönergesini vermiştir. Örneklem topu kutuya atma görevini tamamladığında her defasında bu davranışı pekiştirilmiştir. Örneklem verilen ikinci görevi tamamladıktan sonra son hedef beceri olan legoları yerlerine yerleştirme becerisi için araştırmacı, örnekleme "legoları yerlerine yerleştir" yönergesini vermiştir. Diğer iki hedef becerideki gibi öğrenci her görevi yerine getirme davranış1 sergilediğinde araştırmacı tarafından bu davranışları da yiyecek ve sosyal pekiştireçlerle pekiştirilmiştir. Uygulama süreci sonunda görevi tamamlama davranışı yerine getirdiğinde örneklemin beş dakika tablet bilgisayarla oynamasına izin verilmiştir. Uygulama sürecinde örneklemin yönergeyi algılayıp yerine getirme davranışlarına bağlı olarak araştırmacı, ilk üç öğretim oturumunu sürekli pekiştirme ile yürütmüştür. Daha sonraki üç oturum da ise aralıklı pekiştirme türlerinden olan değişken oranlı pekiştirme kullanılarak, oturumlarda pekiştireç etkisinin düşmesini ve öğrencinin pekiştirece bağlı olarak görevleri tamamlamasının önüne geçilmiştir. Böylece sürekli pekiştirmeden farklı olarak her davranış pekiştirilmemiş örneklemin görevleri tamamlaması davranışları değiş̧en oranlara göre pekiştirilmiştir. Sürekli pekiştirmede kullanılan pekiştireçler aralıklı pekiştirme oturumlarında da kullanılmıştır.

Uygulamalar 40 dakikadan oluşan öğretim oturumlarından oluşmuştur. Her bir öğretim oturumunda dört denemeye yer verilmiştir. Öğretim oturumlarında üç oturum üst üste $\% 100$ düzeyinde ölçüt karşılanıncaya kadar devam edilmiştir. Ölçüt olarak, görevi tamamlama davranışlarında yer alan tanıma uygun olarak örneklemin, verilen görevleri tamamlama davranışını gerçekleştirmesi beklenmiştir. Uygulama sürecine örneklemin problem davranışları ortadan kalkana kadar ve bu davranışlarda kararlılık gösterinceye kadar devam edilmiştir. Böylece uygulama süreci toplamda dört hafta sürmüştür.

\section{İzleme Oturumları}

İzleme oturumları; araştırmacı tarafından öğretim oturumlarından sonraki birinci, ikinci ve üçüncü haftalarda düzenlenmiştir. Araştırmacı oturumlar sırasında örnekleme hedef becerilerin yönergesini vererek örneklemin görevi tamamlama düzeyine bakmıştır. İzleme oturumları sırasında örnekleme herhangi bir yardım veya pekiştireç sunulmamıştır. Ancak oturumlar tamamlandıktan sonra örneklemin görevi tamamlama davranışı pekiştirilmiştir.

\section{Araştırma Verilerinin Güvenirliği}

Araştırma verilerinin güvenirliği; (a) gözlemciler arası güvenirlik ve (b) uygulama güvenirliği şeklinde sunulmuştur. Araştırmada gözlemciler arası güvenirlik, özel eğitim alanında doktora yapan iki özel eğitim öğretmeni olan uzmanların katkılarıyla sağlanmaya çalışılmıştır. Uzmanlar, araştırmacıların "Gözlemciler Arası Güvenirlik Veri Toplama Form'unda" yer alan basamakları yerine getirip getirmediğini kamera kaydından izleyerek uygunsa formda yer alan "evet" sütununa, uygun değilse "hayır" sütununa (+) işaretini koymuşlardır. Başlama düzeyi oturumları, uygulama süreci ve izleme oturumlarına ilişkin tüm oturumların en az \%30'unda araştırmanın video kayıtları, gözlemciler tarafından izlenerek, gözlemciler arası güvenirlik verileri toplanmıştır. Gözlemciler arası güvenirlik hesab1 [(görüss birliği) / (görüş birliği + görüş ayrıllğı)] x 100 formülü kullanılarak hesaplanmıştır. Hedef beceriler için başlama, yoklama, uygulama ve izleme oturumlarına ilişkin güvenirlik yüzdesi \%98 olarak hesaplanmıştır. Gözlemciler arası güvenirliğe ilişkin veriler Tablo 1'de verilmiştir. 
Tablo 1

Gözlemciler Arası Güvenirliğe İlişkin Veriler

\begin{tabular}{cccccc}
\hline Beceri & Uygulama & B.D. & Uygulama & T.Y. & İzleme \\
\hline $\begin{array}{c}\text { Görevi } \\
\text { Tamamlama }\end{array}$ & Video & 100 & 98 & 98 & 98 \\
\hline
\end{tabular}

Anahtar: B.D.: Başlama Düzeyi Yoklama, T.Y.: Toplu Yoklama

Uygulama sırasında, örneklemin görevi tamamlama davranışlarının arttırılmasında sürekli ve aralıklı pekiştirmenin öğretim basamaklarına ilişkin uygulamanın güvenilir bir biçimde gerçekleşip gerçekleşmediğini belirleyebilmek amacıyla uygulama güvenirliğine ilişkin bir form geliştirilmiştir. Uygulama güvenirliğine ilişkin veriler, araştırmacılar tarafından hazırlanan görevi tamamlama davranışları öğretim paketinin uygulama güvenirliğine yönelik hazırlanan form aracılığıyla toplanmıştır. Uygulama güvenirliğine ilişkin veriler; (a) Araştırmacının kendisini ve uygulama esnasında kullanılacak olan araç gereçleri tanıtması, (b) Öğretimsel amaçların, hedef becerilerin ve pekiştireçlerin örnekleme açıklanması, (c) Örneklemin çalışma esnasında ne gibi görevleri olduğu, görevlerini nasıl yerine getireceğinin ve hangi peliştireçleri kazanacağının kendisine açıklanması, d) Örneklemin dikkatinin hedef becerilere çekilmesi, (e) İzleme sürecinde örnekleme görevleri hakkında açıklamalar yapılması, (f) Hedef beceri yönergelerinin doğru sunulması, (h) Örneklemin görevi tamamlama beceri basamaklarını gerçekleştirilmesinin sağlanması, (i) Görev etkinlikleri gerçekleştirildiğinde pekiştireçlerin, pekiştireç tarifesine uygun olarak verilmesi basamaklarından oluşmuştur. Uygulama güvenirliğine ilişkin veriler bütün oturumlar için toplanmıştır. Gözlemci tarafından tüm oturumların \%30'unda uygulama güvenirliğine yönelik veriler elde edilmiştir. Uygulama güvenirliği katsayısı, gözlenen uygulamacı davranışının, planlanan uygulamacı davranışına bölünerek yüzdesinin alınmasıyla hesaplanmıştır (Kırcaali İftar ve Tekin İftar, 2012). Uygulama güvenirliğine ilişkin veriler, görevi tamamlama beceri basamaklarının uygulanışında \%100 olarak bulunmuştur. Uygulama güvenirliğine yönelik veriler Tablo 2'de verilmiştir.

Tablo 2

Uygulama Güvenirliğine İlişkin Veriler

\begin{tabular}{lccccc}
\hline \multicolumn{1}{c}{ Beceri } & Uygulama & B.D. & Öğretim & T.Y. & İzleme \\
\hline Araç-gereçler & Video & 100 & 98 & 100 & 100 \\
Öğretimin tanıtımı & Video & 100 & 100 & 100 & 100 \\
Görevleri açıklama & Video & 100 & 100 & 100 & 100 \\
Dikkat çekme & Video & 100 & 100 & 100 & 100 \\
Hedef beceri sunumu & Video & 100 & 100 & 98 & 100 \\
Pekiştireç sunma & Video & 100 & 100 & 100 & 100 \\
\hline
\end{tabular}

Anahtar: B.D.: Başlama Düzeyi Yoklama, T.Y.: Toplu Yoklama

\section{Sosyal Geçerlik}

Araştırmalarda kuramsal çerçeve ile sınırları çizilen problem durumu, belirli bir soru şeklinde biçimlendirilir (Baltac1, 2019). $\mathrm{Bu}$ araştırmada da otizmli bir bireyin görevi tamamlama davranışlarının artırılmasında sürekli ve aralıklı pekiştirme kullanımı öğretim sürecinde elde edilen sonuçların öğrenci açısından önemini belirleyebilmek için araştırmacılar tarafından yarı yapılandırılmış sosyal geçerlilik formu geliştirilmiştir. Form "Bu çalışma çocuğunuzun görevi tamamlama davranışlarının artmasında ne düzeyde etkili oldu? Araştırmanın hoşunuza giden yanları nelerdir? Araştırmanın hoşunuza gitmeyen yanları nelerdir?" şeklinde açı uçlu üç sorudan oluşmuştur. Örneklem, görevi tamamlama davranışlarının hedef becerilerini \%100 düzeyinde kazandıktan sonra araştırmacılar tarafından aile ziyaret edilerek örneklemin annesiyle sosyal geçerlik formu doldurulmuştur. Araştırmada, örneklemin annesinin, araştırmanın hedefini oluşturan görevi tamamlama davranışlarının artırılmasında sürekli ve aralıklı pekiştirmenin kullanılmasına ilişkin görüşleri alınarak, araştırmanın sosyal geçerliliği incelenmiştir. 
Örneklemin annesi "Bu çalışma çocuğunuzun görevi tamamlama davranışlarının artmasında ne düzeyde etkili oldu?" sorusuna araştırmanın hedefi olan görevi tamamlama davranışlarının artırılmasını "anlamlı bulduğunu, sürekli ve aralıkl pekiştirmenin çocuğunun dikkatini çektiğini" söylemiştir. Ayrıca örneklemin "evde daha önce yapmaktan kaçındĭ̆ bazı görevleri yapmaya başladığını" ifade etmiştir. Örneklemin annesi "Araştırmanın hoşunuza giden yanları nelerdir?" sorusuna ise öğretim oturumlarında sürekli ve aralıklı pekiştirmenin birlikte kullanılmasının çok işe yaradığını söylemiştir. Bu konuda ki görüşünü şöyle açıklamıştır: "Oğlum daha önce bir şey yaptığında hemen ardında yiyecek ya da oyun istiyordu. Sizin öğretim oturumlarında yaptığınız gibi belli aralıklarla pekiştirecin sunulması oğlumun bu davranışının çok azaldığını gördüm." Örneklemin annesi “Araştırmanın hoşunuza gitmeyen yanları var mi, varsa nelerdir? sorusuna da araştırmada beğenmedikleri veya hoşlanmadıkları herhangi bir durumun olmadığını ifade etmiştir. Böylece araştırmanın uygulama sürecine ilişkin sosyal geçerliliği sağlanmaya çalışılmıştır.

Araştırmada, uygulama sürecinde ve öğretim ortamlarında elde edilen veriler grafiksel olarak çözümlenmiştir. Verilerin çözümlenmesi için, grafiksel analiz tekniklerinden çizgisel grafik kullanılmıştır. Örneklemin görevi tamamlama davranışlarına ilişkin puanlar yüzde olarak y ekseni üzerinde 0-100 arasında eşit aralıklarla gösterilmiş, başlama düzeyi 1, uygulama 1, başlama düzeyi 2, uygulama 2 ve izleme verileri x ekseninde numaralandırılmış ve eşit aralıklarla gösterilmiştir.

\section{Araştırma Etiği}

$\mathrm{Bu}$ araştırmada, etik onay ve yazılı izin Van Yüzüncü Yı1 Üniversitesi Sosyal ve Beşeri Bilimleri Yayın Etik Kurulundan 13.05.2020 tarih ve 2020/03-09 sayılı yazıyla alınmıştır. Ayrıca araştırmanın tüm aşamalarında etik kurallara uyulmuştur

\section{Bulgular}

$\mathrm{Bu}$ bölümde örneklemin görevi tamamlama davranışlarının arttırılmasında sürekli ve aralıklı pekiştirmenin etkililik düzeyine ilişkin bulgulara yer verilmiştir. Araştırmada, sürekli ve aralıklı pekiştirmenin görevi tamamlama davranışları üzerinde etkili olduğu, örneklemin öğretim oturumlarından önce düzenlenen başlama düzeyi verilerinde verilen göreve ya başlamadığı ya da başladığı görevi tamamlamadığı bulgulanmıştır. Araştırmada ilk gerçekleştirilen öğretim oturumlarında, örneklemin göreve dikkatini çekmek ve görev basamaklarını gerçekleştirmesi için doğru yaptığ 1 her davranışı pekiştirilmiştir. Sonraki öğretim oturumlarında örneklemin pekiştirece bağımlılığını azaltmak ve görevleri bağımsız bir şekilde gerçekleştirmesini sağlamak amaciyla değişik aralıklarda pekiştirme yapılmıştır. Bu sürecin, örneklemin öğretim oturumları tamamlandıktan sonra da kazanımları sürdürmesini sağladığı görülmüştür. Örneklemin hedef becerileri kazanma ve sürdürme düzeylerine ilişkin bulgular Şekil 1'de gösterilmiştir. Şekil 1'de örneklemle gerçekleştirilen uygulamalar birinci başlama düzeyi A1, birinci uygulama evresi B1, ikinci başlama düzeyi A2, ikinci uygulama evresi B2 şeklinde ve sürdürülebilirlik oturumları ise İ şeklinde gösterilmiştir. 


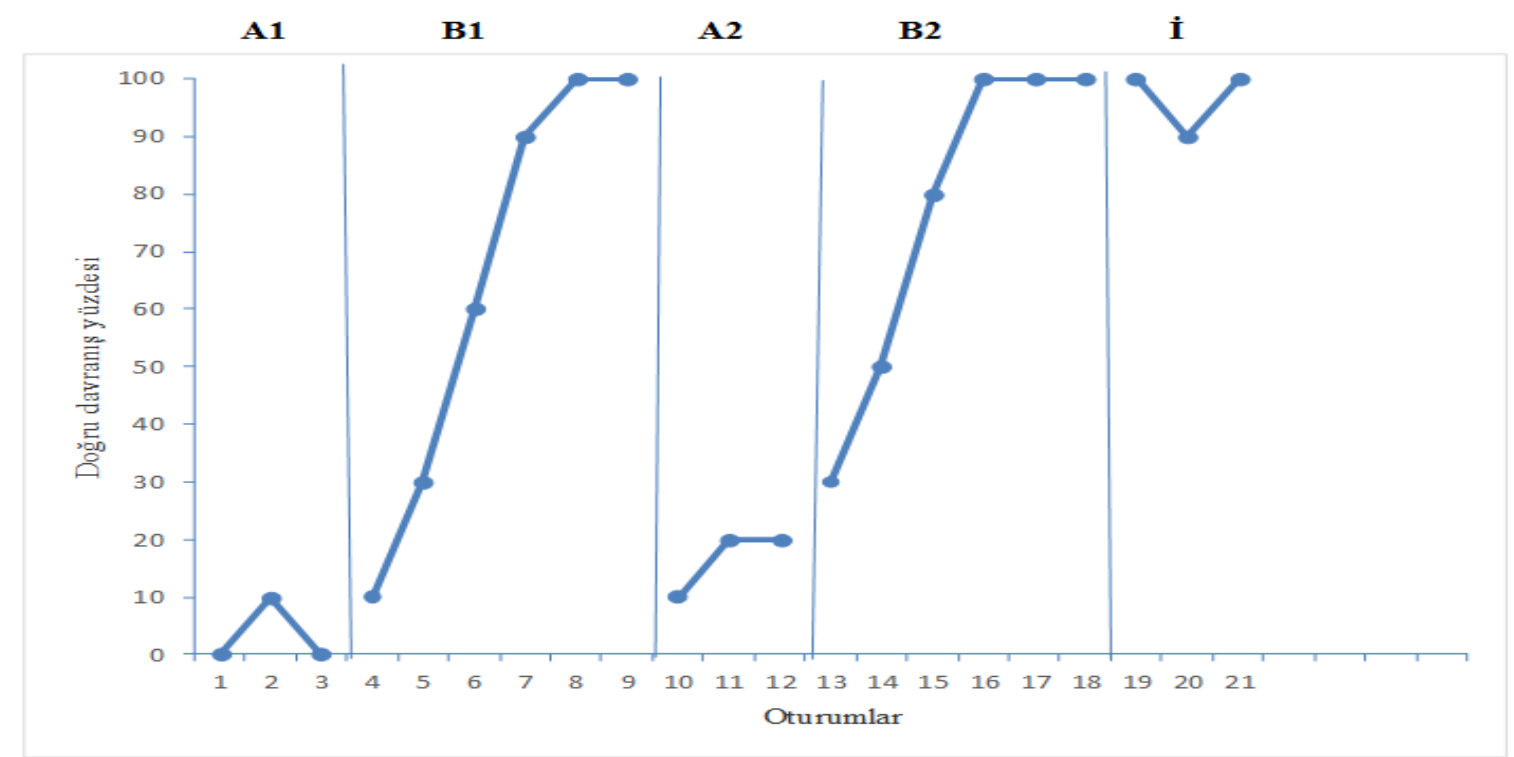

Şekil 1. Otizmli Bir Bireyin Görevi Tamamlama Davranışlarının Artırılmasında Sürekli Pekiştirme ve Aralıklı Pekiştirmenin Etkililiği

Şekil 1'de görüldüğü üzere, birinci başlama düzeyi evresinde (A1) örneklemin hedef beceri olan görevi tamamlama davranışlarına sahip olmadığı bulgulanmıştır. Birinci başlama düzeyi evresinde üç oturum üst üste örneklemin hedef beceriye sahip olmadığı görülünce kararlı veri elde edilmiş ve uygulama evresine geçilmiştir. Uygulama evresinde hedef becerinin öğretimi yapılmıştır. Öğretim evresinde doğru tepki yüzdesinin \%10 ile \%100 arasında değişiklik gösterdiği belirlenmiştir. Örneklem, uygulama evresinde düzenlenen 4., 5. ve 6. oturumlarda hedef beceriyi kabul edilebilir düzey olan \%90-100 ölçütünde sergilemiştir. Bu düzey, istenilen ölçüde performans olduğundan belirlenen ölçüt karşılanmış olup, hedef becerinin birinci öğretim evresi sonlandırılmıştır. Birinci uygulama verileri ile birinci başlama düzeyi verilerinin bir birine benzemediği ve uygulama sonucunda örneklemde anlamlı değişikliğin olması bağımlı değişkenin bağımsız değişkene bağlı olarak değiştiği tahminini doğurmuştur. Araştırmanın modeli gereği bir daha başlama düzeyi verileri toplanmış ve grafikte A2'ye bakıldığında örneklemin hedef beceri doğru tepki yüzdesinin \%10 ile \%20 arasında olduğu görülmektedir. Üç oturum üst üste düzenlenen başlama düzeyi oturumlarında örneklemin hedef beceriyi yerine getirmediği görülmüş ve tahmin doğrulanmıştır. Grafik üzerinde A2 evresi incelendiğinde kararlı veri elde edildikten sonra ikinci uygulama olan B2'ye geçildiği görülmektedir. B2'de örneklemin görevi tamamlama davranışları doğru tepki yüzdesinin \%25 ile \%100 arasında olduğu görülmektedir. İkinci uygulama evresi olan B2'deki verilerin A2 verilerine benzemeyip B1 verileriyle paralellik gösterdiği görülmüştür. Dolayısıyla A2'de doğrulanan tahmin yinelenmiştir. Örneklem, ikinci uygulama evresinde düzenlenen 4., 5. ve 6. oturumlarda hedef beceriyi kabul edilebilir düzey olan \%100 ölçütünde sergilemiştir. Bu düzey, istenilen ölçüde performans olduğundan belirlenen ölçüt karşılanmış olup, hedef becerinin ikinci öğretim evresi sonlandırılmış ve izleme verilerine yer verilmiştir. Örneklemin hedef becerilerinin öğretimine ilişkin öğretim sona erdikten bir, iki ve üç hafta sonra düzenlenen izleme oturumlarında görevi tamamlama davranışlarının \%90-100 düzeyinde sergilendiği bulgulanmıştır.

\section{Sonuç, Tartışma ve Öneriler}

Araştırmada, OSB'li bir bireyin görevi tamamlama davranışlarının artırılmasında sürekli ve aralıklı pekiştirme kullanılmıştır. Bir öğretim uygulamasında pekiştirmeden söz etmek için, davranışı izleyen durumların, davranışın sıklık ve süresi üzerinde olumlu etki bırakması gerekmektedir (Cooper, Heron ve Heward, 2007). Pekiştireçleri belirlerken ve kullanırken pekiştirecin bireyin yaşına, ilgilerine ve isteklerine uygun olması, pekiştirecin davranışın hemen ardından verilmesi ve pekiştireçlerin küçük miktarda sunulması gerekir. Ayrıca diğer pekiştireçlerin sosyal pekiştireçlerle eşlenmesi, premack ilkesinin benimsenmesi, davranışın tanımlanması, pekiştireçlerin çeşitlendirilmesi, belli aralıklarla 
pekiştireç değerlendirilmesinin yapılması ve pekiştireçlerin zamanla silikleştirilmesinin gerçekleştirilmesine dikkat edildiğinde örneklemin pekiştireçten etkilenmesi ve dolayısıyla öğretim uygulamasının başarılı olması sağlanmış olur (Yücesoy Özkan, Kaya ve Gülboy, 2017). Problem davranışları ortadan kaldırmak amacıyla gerçekleştirilen öğretimlerde araştırmacılar, pekiştireçlerin davranış üzerindeki etkisini azaltmak ve doğal koşullarda uygulama sırasında sunulan pekiştireçler olmadan davranışların sergilenebilmesi için pekiştireçleri silikleştirmelidirler. Dolayısıyla öğretimlerde ilk başlarda davranışlar daha sık pekiştirilirken, sonraki aşamalarda pekiştirme daha az sıklıkta yapılmalıdır (Kurt, 2012). OSB'li bireylerin temel problem davranışlarından birisi de bazı davranışları normalden fazla sergilemeleri, bazılarını ise çok az ya da hiç sergilememeleridir. $\mathrm{Bu}$ özelliklerinden dolayı OSB'li bireyler için hazırlanan öğretim programlarında pekiştirme ve davranışların pekiştirme yapacağ 1 şartları belirleyen çevresel uyarlamalar için pekiştirme durumunun sınırlarını çizen pekiştirme tarifelerinin dikkatlice uygulanması önemlidir (Akmanoğlu, 2012). Bu araştırmada da, alanyazında OSB'li bireyler için vurgulanan ifadelere paralel olarak, OSB'li bireyin gelişimini ve tercihlerini ortaya koymak amacıyla doğrudan ve dolaylı gözlemler yapılmış, davranışsal olarak değerlendirmeler gerçekleştirilmiş, bireye uygun pekiştireçler ve pekiştirme tarifeleri belirlenmiştir. Örneklemin sıklıkla sergilediği görevi tamamlamaktan kaçınma problem davranışlarının azaltılması ve görevi tamamlama davranışlarının artırılması için sürekli ve aralıklı pekiştirme uygulamaları sonucunda, örneklemin problem davranışının ortadan kalktı̆̆1 ve uygulama sona erdikten sonrada örneklemin bu davranışları sürdürdüğü sonucuna ulaşılmıştır. Araştırma sonuçları, alanyazında pekiştirme kullanarak uygulanan birçok araştırma (Dayı ve Şafak, 2018; Eldeniz Çetin 2017; Erbaş, 2005; LeBlanc, Carr, Crossett, Bennett ve Detweiler, 2005; Özkubat ve Töret, 2014; Ricciardi ve Luiselli, 2003; Saloviita, 2002; Sönmez ve Varol, 2008; Sönmez ve Varol, 2009) sonuçlarını destekler niteliktedir. Ayrıca araştırma sonuçları Bouck vd. (2014) ile Rosenbloom, Wills, Mason, Huffman ve Mason (2019) araştırma sonuçlarıyla da örtüşmektedir. Bouck vd. (2014) araştırmalarında şu sorulara: a) Öğrenciler kendi kendini gözlemlerken görevleri bağımsız bir şekilde gerçekleştirecekler mi? b) Geleneksel kağıt/kalem ve teknoloji tabanlı araçlar karşılaştırıldığında, istem sayısı ve görev bağımsızlı̆̆ı farklılık gösterecek mi? c) Geleneksel kağıt/kalem ve teknoloji tabanlı araçlar karşılaştırıldığında, öğrencilerin görevleri tamamlama süreleri farklılık gösterecek mi? ve d) Öğrencilerin kendilerini gözlemlemek için kağıt $/ \mathrm{kalem}$ veya teknoloji kullanımına bakış açıları nelerdir? yanıt aramışlardır. Araştırma sonucunda görevi bağımsız gerçekleştirmek için öğretim programlarının işe yaradığını ve bireylerin hayat akışlarını kolaylaştırdığını ortaya koymuşlardır. Benzer bir şekilde Rosenbloom, Wills, Mason, Huffman ve Mason (2019) kendi kendini izlemenin görevi bağımsız bir şekilde sağlama üzerine yaptıkları arştırmalarında şu sorulardan hareketle: a) OSB olan bireylerin kendi kendini izleme müdahalesi ile görev başındaki davranışları arasında işlevsel bir ilişki var mı? b) Kendi kendini izleme müdahalesi ile OSB olan bireylerin problem davranışları arasında doğal bir ilişki var mı? ve c) Kendi kendini izleme müdahalesi ile OSB olan bireylerin görev tamamlama yüzdesi arasında doğal bir ilişki var mı? araştırmalarını yürütmüşlerdir. Araştırma sonucunda tüm örneklemlerde görevi tamamlama davranışlarının arttığ 1 ve problem davranışlarının azaldığı görülmüştür. $\mathrm{Bu}$ araştırma sonuçlarında da örneklemin görevi tamamlama davranışalarının arttığı ve bunun bir sonucu olarak göreve katılmama, görevi sürdürmeme ve görevi tamamlamama problem davranışalrının ortadan kalktığı görülmüştür.

Araştırmada, örneklemin görevi tamamlama davranışlarının artırılması için sürekli ve aralıklı pekiştirmenin birlikte kullanılması, uygulamacı, örneklem ve örneklemin ailesi için olumlu sonuçlar doğurduğuna ilişkin şu sonuçlara ulaş1lmıştır:

a) Hedef davranışların sergilenme süresi artmıştır.

b) Görevi tamamlama davranışlarındaki artışlarda, yalnızca pekiştirmeye bağlı olmaksızın sergilendiği görülmüştür.

c) Örneklemin pekiştireçlere kolayca doyuma ulaşmasının önüne geçtiği için pekiştirecin, pekiştirici etkisinde herhangi bir düşüş kaydedilmemiştir. 
d) Sürekli pekiştirmeden sonra aralıklı pekiştirmenin uygulanması sonucunda, pekiştireçlerin davranış üzerindeki etkisinin giderek azaldığı ve davranışın doğal olarak sergilendiği gözlenmiştir.

e) Örneklemin öğretmeni ve ailesi, araştırma uygulamalarından önce örneklemin problem davranış sergilemesinin önüne geçmek amacıyla genellikle örneklemin istediği şeyi vermiş̧lerdir. Bu da pekiştirecin asıl görevinden ziyade örneklemin problem davranışlarını sürdüren bir başka amaca hizmet etmesine neden olduğunu ortaya koymuştur. Bu araştırma sonucunda sürekli ve aralıklı pekiştirmenin birlikte kullanılmasının örneklemdeki bu yanlış öğrenmeyi düzelttiği ve pekiştireçlerin silikleştirilmesinde olumlu etkiye yol açtı̆̆ görülmüştür.

f) Araştırmacıların, araştırmanın hangi aşamasında hangi sıklıkta pekiştireç sunacaklarını bilmelerine ilişkin sistematik bir yol izlendiği için araştırmanın kolay uygulanmasını sağlamıștır.

g) Örneklemin görevi tamamlama davranışlarını hızlıca kazanmasını sağlamıştır.

h) Örneklemin ailesi, programı beğendiklerini ve öğretim için farklı bir bakış açısı kazandıklarını ifade etmişlerdir.

i) Program, kazanılan davranışların öğretim sona erdikten sonra da sürmesini olumlu yönde etkilemiştir.

Araştırmada otizmli bireyler için pekiştireçlerin belli pekiştirme tarifeleriyle uygulanması ve sistematik olarak geri çekilmesinin önemli olduğu sonucuna da varılmıştır. Araştırmada sürekli ve aralıklı pekiştirmenin, örneklemin görevi tamamlama davranışlarında artma ve görevi sürdürme davranışlarında olumlu etkiye yol açtığı saptanmıştır.

$\mathrm{Bu}$ araştırmada, ilerde yapılacak araştırmalar için, bir öğretim programı hazırlanırken örnekleme yönelik pekiştireç belirleme safhasında bazı değerlendirmelere ve gözlemlerin yapılması önerilmektedir. Ayrıca, ileri araştrımalar için bu konunun birden çok örnekleme yönelik yapılması ve uygulamada başka bir öğretim modeli kullanılarak araştırmanın yürütülmesi önerilmektedir. Görevi tamamlama davranışlarına yönelik ileri teknolojik aygıtlar kullanılarak etkisinin belirlenmesine yönelik de araştırmaların yapılması önerilmektedir.

\section{Yazarların Katkı Oranı}

Bu makaleye birinci yazarın \%50, ikinci yazarın $\% 50$ oranında katkısı vardır.

\section{Çıkar Çatışması}

$\mathrm{Bu}$ çalışmada çıkar çatışması oluşturacak bir husus yoktur.

\section{Kaynaklar}

Acar, Ç. (2000). Zihin özürlü çocuklarla çalışan özel ĕgitim öğretmenlerinin sinıflarında karşılaştıkları problem davranışlarla ilgili görüş ve önerileri. Yüksek Lisans Tezi, Anadolu Üniversitesi, Eğitim Bilimleri Enstitüsü, Eskişehir.

American Psychiatric Association, (2013). Diagnostic and statistical manual of mental disorders. Arlington, VA: American Psychiatric Association;

Akmanoğlu, N. (2012). Otizm spektrum bozukluğu olan çocuklara uygun ve yeni davranışların kazandırılması ve artırılması. E. Tekin-İftar (Ed.), Otizm spektrum bozukluğu olan çocuklar ve eğitimleri içinde (ss. 121-181). Ankara: Vize Yayıncılık.

Alan, S. ve Özsoy, G. (2019). Problem genişletme etkinliklerinin problem çözme başarısına ve üstbilişe etkisi. Ahi Evran Üniversitesi Sosyal Bilimler Enstitüsü Dergisi, 5(2), 439-458. 
Aydın, A. (2008). Otizmde ilk adım. İstanbul: Epsilon Yayıncılık.

Baltacı, A. (2019). Nitel araştırma süreci: Nitel bir araştırma nasıl yapılır?. Ahi Evran Üniversitesi Sosyal Bilimler Enstitüsü Dergisi, 5(2), 368-388.

Besler, f. ve Süzer, T. (2012). Pekiştirme. E. Tekin-İftar (Ed.), Uygulamalı Davranış Analizi içinde (ss. 213-266). Ankara: Vize Akademi.

Bullock, L. M., \& Brown, R. K. (1972). Behavioral dimensions of emotionally disturbed children. Exceptional Children, 38(9), 740-742.

Bouck, E. C., Savage, M., Meyer, N. K., Taber-Doughty, T., \& Hunley, M. (2014). High-tech or lowtech? Comparing self-monitoring systems to increase task independence for students with autism. Focus on Autism and Other Developmental Disabilities, 29(3), 156-167.

Carr, E. G., Levin, L., McConnachie, G., Carlson, J. I., Kemp, D. C. and Smith, C. S. (1994). Communication-based intervention for problem behavior: a user's guide for producing positive change. Baltimore: Paul H. Brookes.

Cavkaytar, A. (2015). Otizm spektrum bozukluğu (1. Bask1). Ankara: Aile ve Sosyal Politikalar Bakanlığ , Grafik-Ofset Matbaacilık.

Clifford, S., Young, R. and Williamson. P. (2007). Assessing the early characteristics of autistic disorder using video analysis. Journal of Autism and Developmental Disorder, 37(2) $301-313$

Cooper, J.O., Heron, T.E. and Heward, W. L. (2007). Applied behavior analysis. Upper Saddle River, NJ: Pearson Prentice Hall.

Çopuroğlu, Y. C. ve Mengi A. (2014). Toplumsal Dışlanma ve Otizm. Turkish Studies, 9(5), 607-626.

Darıca, N., Abidoğlu, Ü. ve Gümüşçü, Ş. (2002). Otizm ve otistik çocuklar. İstanbul: Özgür Yayınları.

Dayı, E. ve Şafak, P. (2018). Çoklu Yetersizliği olan bir çocuğa dönüştürülebilir sembol pekiştirmeyi içeren tuvalet eğitim paketiyle tuvalet kontrolünün kazandırılması: vaka çalışması. Ĕgitim ve Bilim Dergisi, 43(196), 301-316.

DeLeon, I. G., Fisher, W. W., Rodriguez-Catter, V., Maglieri, K., Herman, K. and Marhefka, J. M. (2001). Examination of relative reinforcement effects of stimuli identified through pretreatment and daily brief preference assessments. Journal of Applied Behavior Analysis, 34(4), 463-473.

Diken, İ.H. ve Bakkaloğlu, (2016). Zihinsel yetersizliği ve otizm spektrum bozukluğu. Ankara: Pegem Akademi Yayınc1lık.

Duran, V. M. ( 1999). Functional communication training using assitive devices: recruiting natural communities of reinforcement. Journal of Applied Behavior Analysis, 32, 247-267.

Durand, V. M. and Carr, E. G. (1992). An analysis of maintenance following functional communication training. Journal Of Applied Behavior Analysis, 259, 777-794.

Eldeniz Çetin, M. (2017). Özel gereksinimli bireylerin tercihlerinin değerlendirilmesi. Ankara Üniversitesi Eğitim Bilimleri Fakültesi Özel Eğitim Dergisi, 18(2), 309-328. 
Erbaş, D. (2001) Gelişimsel geriliği olan çocukların problem davranışlarının azaltılmasında işlevsel iletişim ögretiminin sönmeyle birlikte ve sönme olmaksızın uygulanmasının etkililiklerinin karşılaştırılması. Doktora tezi, Anadolu Üniversitesi, Sosyal Bilimler Enstitüsü, Eskişehir.

Erbaş, D. (2005) Olumlu davranışsal destek. Ankara Üniversitesi Eğitim Bilimleri Fakültesi Özel Eğitim Dergisi, 6(1), 1-18.

Erbaş, D. (2017). Problem davranışların işlevlerini belirleme. D. Erbaş ve Ş. Yücesoy-Özkan (Ed.), Uygulamalı davranış analizi içinde (ss. 215-264). Ankara: Pegem Akademi Yayınları.

Girli, A. (2004). Otistik çocuklar ve aileleri (1. Bask1). İzmir: Işık Özel Eğitim Yayınları.

Kadak, M. T., Demir, T., ve Doğangün, B. (2013). Otizmde yüz ve duygusal yüz ifadelerini tanıma. Psikiyatride güncel yaklaşımlar-current approaches in psychiatry, 5(1), 15-29.

Hume, K., Loftin, R., \& Lantz, J. (2009). Increasing independence in autism spectrum disorders: A review of three focused interventions. Journal of ASD and Developmental Disorders, 39, 1329 1338. https ://doi.org/10.1007/s1080 3-009-0751-2.

Kanner, L. (1943). Autistic disturbances as affective contact. Nervous child, 2, 100-250.

Kuhn R. and Cahn C. H. (2004). Eugen Bleuler's concepts of psychopathology. Hist Psychiatry 15(3), 361-366.

Kunt. S. (2010). Otizm el rehberi. İstanbul: Sistem yayıncılık.

Kurt, O. (2012). Davranış artırma ve azaltma yöntemleri. E. Tekin-İftar (ed). Eğitim ve davranış bilimlerind tek-denekli araştırmalar içinde (ss. 41-69). Ankara: Türk Psikologlar Derneği Yayınları.

Kurt, O. ve Subaş1-Yurtçu, A. B. (2017). Otizm spektrum bozukluğu olan bireylere yönelik kapsamlı uygulamalar. Sakarya University Journal of Education, 7(1), 155-182.

Lee, D. L. and Belfiore, P.J. (1997). Enhancing classroom performance: A review of reinforcerment schedules. Journel of Behaviorel Education, 7(2), 205-217.

LeBlanc, L. A., Carr, J. E., Crossett, S. E., Bennett, C. M. and Detweiler, D. D. (2005). Intensive outpatient behavioral treatment of primary urinary incontinence of children with autism. Focus on Autism and Other Developmental Disabilities, 20(2), 98-105. Doi: $10.1177 / 10883576050200020601$.

Mengi, A. (2019). Sosyolojik boyutlarıla otizm. Ankara: Anı yaync1l1k.

Odom, S., Coolet-Klinenberg, L., Rogers, S. and Hatton, D. (2010). Evidence-based pratices in interventions for children and youth with autism spectrum disorder. Preventing School Failure, 54, 275-282.

Özdemir, O. (2014). Otizm daranış kontrol listesi türkçe versiyonu geçerlik ve güvenirlik çalışmaları. Doktora Tezi, Anadolu Üniversitesi, Eğitim Bilimleri Enstitüsü, Eskişehir.

Özkubat, U. ve Töret, G. (2014). Zihinsel yetersizliği olan çocuklara gündüz tuvalet kontrolü becerisi öğretiminde anneleri tarafindan sunulan geleneksel gündüz tuvalet kontrolü öğretiminin etkililiği. Pamukkale Üniversitesi Ĕ̆itim Fakültesi Dergisi, 35(1), 61-84. 
Özyürek, M. (2000). Olumlu sinıfyönetimi. Ankara: Kök Yayıncılık.

Özyürek, M. (2010). Problem davranışları değiştirme. Ankara: Kök Yayıncılık.

Peterson, C., Lerman, D.C. and Nissen, M.A. (2016). Reinforcer choice as an antecendent versus consequence. Journel of Applied Behavior Analysis, 49(2), 286-293.

Richman, D. M., Wacker, D. P. and Winborn, L. (2001). Response efficiency during functional communication training: effects of effort on responce allocation. Journal of Applied Behavior Analysis, 34(1), 73-76.

Ricciardi, J. N. and Luiselli, J. K. (2003). Behavioral intervention to eliminate socially mediated urinary incontinence in a child with autism. Child and Family Behavior Therapy, 25(4), 53-63. Doi: 10.1300/J019v25n04_04.

Rosenbloom, R., Wills, H. P., Mason, R., Huffman, J. M., \& Mason, B. A. (2019). The effects of a technology-based self-monitoring intervention on on-task, disruptive, and task-completion behaviors for adolescents with autism. Journal of autism and developmental disorders, 49(12), 5047-5062.

Rush, K. S., Mortenson, B. P. and Birch, S. E. (2010). Evaluation of preference assessment procedures for use with infants and toddlers. International Journal of Behavioral Consultation and Therapy, 6(1), 1-15.

Saloviita, T. (2002). Dry bed training method in the elimination of bed-wetting in two adults with autism and severe mental retardation. Cognitive Behaviour Therapy, 31(3), 135-140. Doi: $10.1080 / 165060702320338013$.

Sucuoğlu, B. (2009). Otizm ve otistik bozukluğu olan çocuklar. A. Ataman, (Ed), Özel eğitime giriş içinde (ss. 291-312). Ankara: Gündüz Eğitim ve Yayıncılık.

Sucuoğlu, B. (2012). Otizm spektrum bozukluğu olan çocukların problem davranışlarının azaltılması. E. Tekin-İftar (Ed), Otizm Spektrum Bozukluğu Olan Çocuklar ve Ë̆itimleri (ss. 183-236). Ankara: Vize Yayınc1lık.

Sönmez, M. ve Vuran, S. (2008). Sosyal geçerlik kavramı ve türkiye'de özel eğitim alanında yürütülen lisansüstü tezlerde sosyal geçerliğin değerlendirilmesi. Ankara Üniversitesi Ĕ̈itim Bilimleri Fakültesi Özel Ĕgitim Dergisi, 9(1), 55-65.

Sönmez, N. ve Varol, N. (2008). Eve dayalı aile eğitimi programının zihinsel engelli çocukların gündüz tuvalet kontrolünü kazanmasına ve sürdürmelerine etkisi. Eğitim Bilimleri ve Uygulama, 7(14), 139-155.

Sönmez, N. ve Varol, N. (2009). Annelere eve dayalı gündüz tuvalet kontrolü öğretme becerilerinin kazandırılması. Eğitim Bilimleri ve Uygulama, 8(16), 159-178.

Tekin-İftar, E.(2012). AB modelleri. E. Tekin-İftar, (Ed.). Eğitim ve davranış bilimlerinde tek denekli araştırmalar içinde (ss.155-178). Ankara: Vize.

Tekin-İftar, E. ve Değirmenci, H. D. (2012). Otizm spektrum bozukluğu olan çocukların öğretimi. E. Tekin- İftar (Ed.), Otizm spektrum bozukluğu olan çocuklar ve eğitimleri içinde (ss. 267-321). Ankara: Vize Yayıncilık.

Tekin-İftar, E ve Kırcaali-İftar, G. (2019). Yanlışsız öğretim yöntemleri. Ankara: Vize Akademik. 
Toper Korkmaz, Ö. (2017). Etkili pekiştireçlerin değerlendirilmesinde kullanılan sistematik yöntemler. Ankara Üniversitesi Eğitim Bilimleri Fakültesi Özel Eğitim Dergisi, 18(1) 149164.

Töret, G. (2016). Oizm spektrum bozukluğu (OSB): özellikler. İ. H. Diken ve H. Bakkaloğlu (Ed.). Zihinsel yetersizliği ve otizm spektrum bozukluğu içinde (ss. 192-222). Ankara: Pegem Akademi Yayıncilık.

Wall, K. (2004). Autism and earlyyear spractice: A guide for earlyyear sprofessionals, teachers and parents. London: Paul Chapman.

Yücesoy Özkan, Ş., Ergenekon, Y., Çolak, A. ve Kaya, Ö. (2014) . Otizm spektrum bozukluğu aile bilgilendirme rehberi. Ankara: Aile ve Sosyal Politikalar Bakanlığı

Yücesoy Özkan, Ş., Kaya, F. ve Gülboy, E. (2017). Uygun davranışları artırma. D. Erbaş ve Ş. Yücesoy-Özkan (Ed.), Uygulamalı davranış analizi içinde (ss. 274-329). Ankara: Pegem Akademi Yayınları 


\section{Extended Abstract}

\section{Introduction}

As a subject matter on which experts of different disciplines conduct several research studies and which is drawing more and more attention each day, ASD is a congenital neurobiological disorder (Kunt, 2010). Disruptions are observed in language and communication skills, social interaction skills, mental functions and motor skills of individuals with ASD (Clifford, Young and Williamson, 2007); therefore, they are different than their normally-developing peers (Mengi, 2014). With the problems manifested in using non-verbal communication styles among individuals with ASD, both receptive language and expressive language problems may be observed (Diken and Bakkaloğlu, 2016; Webber and Scheuermann, 2008). Such individuals who cannot use language efficiently may exhibit problem behaviors as a tool of communication (Winborn et al., 2002). Communication problems experienced by individuals with ASD in social interaction cause them to exhibit problem behaviors (Girli, 2004). This affects frequency and duration of engagement in an activity negatively (Erbaş, 2017). Individuals who have inability in such domains in regard to ASD need an educational environment structured to allow them to take normally-developing individuals as models and learn several skills on their own (Tekin İftar and Değirmenci, 2012). It is emphasized that communication skills of children with ASD should be improved through education to mitigate and eliminate problem behaviors such as aborting tasks, hitting, biting, and scattering (Sönmez and Vuran, 2008; Sucuoğlu, 2009). Reducing problem behaviors which have adverse effects on individual's life is of great importance in the socialization of individuals with ASD (Durand and Carr, 1992). It is important that methods to be used for reducing problem behaviors of individuals with ASD are evidence-based (Odom, Coolet Klinenberg, Rogers and Hatton, 2010). Reinforcement is among evidence-based practices of which effect has been proven on the education of individuals with ASD in experimental research studies.

Diken and Bakkaloğlu (2016) state that making arrangements in the education of individuals with ADS in line with their development and preferences affects educational outputs positively. It is considered important to explore whether problem behaviors of such individuals are reduced and to what extent they achieve their tasks once arrangements in line with development and preferences of individuals with ASD are made and appropriate reinforcements are used. It is seen in the relevant literature that there are limited number of studies testing the effect of reinforcement schedules in eliminating problem behaviors of individuals with ASD. Hence, it was deemed important to explore the effectiveness of using continuous and interval reinforcement in improving task-achieving behaviors of an autistic child.

\section{Method}

The research was conducted with the $\mathrm{ABAB}$ research design of single-subject research designs. The participant of the research was a 5-year-old boy diagnosed with ASD. The participant was given the codename Mehmet. Mehmet is a child who avoids communicating with his peers, abort the given tasks or do not start them at all. When he is going to want something or reject something he has been given, he usually cries, weeps and causes crisis. The research was conducted in a room of the participant's home. Collection of all data regarding the starting, implementation, and monitoring sessions of the research was performed in the same environment. It was ensured that only the researcher and the participant were present in the research environment.

To determine the reinforcers preferred by the student, indirect and direct reinforcer determination methods were used. At the end of the interviews, it was thought that education could be provided through the effective and systematic use of reinforcers to eliminate the problem behavior of task abortion. Hence, it was decided to reinforce all desirable behaviors to be exhibited by Mehmet and increase their frequency or duration in the first place, and then, to use interval reinforcement in the implementation. 
In the starting sessions, the student was provided with directives without any instruction and reinforcement. Mehmet did not achieve the tasks he was given and exhibited behaviors such as crying, trying to leave the room and throwing away the activity materials. In the instruction sessions, the first three instruction sessions were conducted by the instructor with continuous reinforcement in compliance with student's behaviors of perceiving the directive and delivering it. In the next three instruction sessions, variable-ratio schedule of reinforcement which is a type of interval reinforcement was utilized to prevent decreased reinforcer effect and to stop the student from achieving the tasks depending on the reinforcer. The implementation process continued until student's problem behaviors were eliminated and such elimination was stable. The monitoring data were collected after the implementation had ended. The data were analyzed graphically.

\section{Findings}

It was concluded in the research that task-achieving behaviors of the individual with ASD were improved when arrangements were performed in accordance with individual's development and preferences and the required reinforcements were utilized. In the starting phase, it was observed that Mehmet did not possess the task-achieving behaviors which were the target skill. In the implementation phase, the target skill was taught to the participant. It was observed that the participant exhibited the task-achieving behaviors by $90-100 \%$ in the monitoring sessions held one week, two and three weeks following the instruction of the target skill. Social validity of the study was also examined by taking the opinions of participant's mother in the research. The mother reported that she found the improvement of task-achieving behaviors meaningful, that use of continuous and interval reinforcement was useful in this instruction, and that she liked the research.

\section{Conclusion, Discussion and Recommendations}

At the end of continuous and interval reinforcements performed to reduce problem behaviors of avoiding completing the task which had been often exhibited by the participant and to improve his task-achieving behaviors, it was found that problem behavior of the participant was eliminated and the participant continued to exhibit task-achieving behaviors after the procedure. Using continuous and interval reinforcement together to improve task-achieving behaviors of the participant led to positive outcomes for the instructor, the participant, and his family. It is important for individuals with ASD that reinforcers are utilized with certain reinforcement schedules and systematically withdrawn. When preparing an instructional program, it is recommended to conduct certain evaluations and observations in the phase of determining the reinforcers specific for the participants. It was found in this research that continuous and interval reinforcement had a positive impact on improving and maintaining participant's task-achieving behaviors. It is recommended for future studies to work with multiple participants or include another instructional model in this program. 